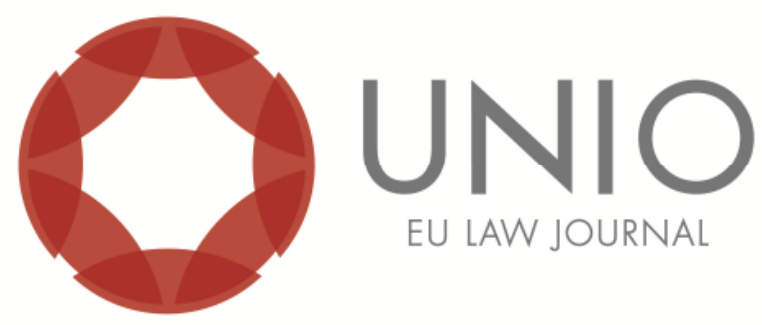

\title{
The Statute of Refugees: Is it Applicable to Environmentally Displaced Persons?
}

\author{
Maria Cláudia da Silva Antunes de Souza* \\ Lucas de Melo Prado*
}

\begin{abstract}
The increasingly frequent occurrence of environmental disasters and natural resource degradation jeopardize the quality of life of humankind and, in some cases, prevents people from remaining in their places of origin. The backdrop of this article is the increasing concern in regards to people forced to abandon their homes, due to environmental changes that render the place they live inhospitable for buman survival. The article has the objective to verify if and under which circumstances the global system of refugee protection is applied to environmentally displaced persons, filling in the lack of rules regulating their situation and ensuring their Fundamental Rights. Accordingly, it is necessary to build a specific legal system for environmentally displaced persons that guarantees people in that condition an effective protection.
\end{abstract}

KE YWORDS: refugee - environmentally displaced person.

\footnotetext{
* Professor at the Programme of Post-Graduation Stricto Sensu in Legal Science, University of Vale do Itajaí - UNIVALI - Brazil.

* Master degree in Legal Science at University of Vale do Itajaí - UNIVALI - Brazil.
} 


\section{Introduction}

The alarming increase in environmental disasters and environmental resource degradation generates a deep concern on the global scene. There are more than 33 million $^{1}$ refugees, refuge requesters, internally displaced persons and other persons who have abandoned their homes, risking their own lives, freedom and security, in the attempt to flee from persecution for reasons relating to race, religion, nationality, membership of a particular social group or political opinion. The international community recognizes those people as refugees. It lends them assistance and gives them asylum through the actions of the United Nations High Commissioner for Refugees (UNHCR) and according to the rules of the 1951 Convention relating to the Statute of Refugees (hereinafter only the 1951 Convention or the Refugee Convention) and its 1967 Protocol Relating to the Statute of Refugees (hereinafter only the 1967 Protocol or the Refugee Protocol).

However, that number does not include other millions of individuals who have also been forced to abandon their homes and risk their own lives, freedom and security, due to environmental changes that have rendered their homes completely unsuitable for human survival. These individuals, refered to as environmentally displaced persons (EDPs), do not have a legal statute of their own as do refugees, and thus they suffer without any effective or directed action from the international community to ensure their fundamental rights. As highlighted by the preamble of the Convention Project Relating to the International Statute of Environmentally Displaced Persons, from the Centre de Recherche Interdisciplinaire en Droit de l'Environnement, de l'Aménagement de de l'Urbanisme (CRIDEAU):

"[...] regardless the various international instruments aiming to protect the environment, there is not, in the current state of international law applicable to refugees, any specific instrument that provides for the situation of the ensemble of environmentally displaced persons and that can be applicable and invoked in their favor." 2

The objective of this article is to provide an analysis of the new category "Environmentally Displaced Persons" and its objective is to verify if (and under which circumstances) the Refugee Convention and Protocol may be applied to these so called EDPs, filling in the lack of norms establishing a statute of their own and protecting their fundamental rights. In this sense, it is needed to build a specific legal system to EADs, guaranteeing persons in such situation an effective protection $^{3}$.

1 33.924.476. This is the number of people under the responsibility of the UNHCR. UNHCR official data, accessed May 02, 2012, http://www.acnur.org/t3/portugues/recursos/estatisticas/.

2 Michel Prieur et al., "Projet de Convention Relative Au Statut International Des Déplacés Environnementaux," 2008, accessed April 11, 2012, http://www.observatorioeco.com.br/wpcontent/uploads/up/2010/09/projet-de-convention-relative-au-statut-international-des-daplacasenvironnementaux2.pdf. Préambule. Free translation. Original text in French: "[...] malgré les nombreux instruments internationaux visant à protéger l'environnement, il n'existe, dans l'état actuel du droit international applicable aux réfugiés, aucun instrument spécifique prévoyant la situation d'ensemble des déplacés environnementaux et pouvant être appliqué et invoqué en leur faveur."

3 In the phases of investigation, data handling and composition of the research final report, an inductive methodological posture was adopted. The category technique and the operational definition technique were operated in order to define clearly the terms used in this article as well as to establish the connections between them. The bibliographical research was duly directed by the referent technique and the data was registered using the record card technique. About the category technique, v. Cesar Luiz Pasold, Metodologia da Pesquisa Juridica: Teoria e Prática, 11 th ed. (Florianópolis: Conceito Editorial; Millennium, 2008), 25-35. About the operational definition technique, v. 37-52. About the referent technique, v. 53-62. About the record card technique, as well as its use with the referent technique, v. 107-123. 
The article is organized as follows: first, the regime adopted by the 1951 Convention for Refugees is presented, highlighting the operational definition ${ }^{4}$ of that category and the criteria for the acknowledgement of the Refugee quality. Then, the matter of EDPs is approached, defining that category and examining the complexity of phenomena included in such category. Finally, the matter of the possibility or impossibility of application of the 1951 Convention to Environmentally Displaced Persons is faced.

\section{Who is Refugee?}

According to the UNHCR, the world had more than 10 million Refugees as at the end of $2010^{5}$. No wonder Earl Huyck and Leon Bouvier stated that "[...] today one may point almost anywhere on a spinning globe and put a finger on a refugee situation"

Even though the existence of refugees dates back to biblical eras - one may think of the exodus of slaves from Egypt, under Moses' leadership, in search of the Promised Land - , the international community demonstrated any concern about the matter only after World War I, with the creation of the League of Nations. Without ever defining the term refugee, the League acted pragmatically and episodically, protecting specific groups through the development of empirical institutional mechanisms, whose extension depended on political considerations and humanitarian empathy. ${ }^{7}$

Only after World War II did the international protection of refugees gain general acclaim, based on two fundamental aspects, as José Henrique Fischel de Andrade highlights: an institutional one, "[...] materialized in the establishment of organizations that intend to assist and protect refugees [...]"s; as well as a legal one, "[...] which happens through the composition of conventional, extra conventional and domestic instruments which define the term 'refugee' and establish the legal status of their beneficiaries"". Today, the institutional aspect is represented by the UNHCR, whilst the legal aspect is materialized in the 1951 Convention and the 1967 Protocol.

As the legal base of global refugee protection, the 1951 Convention presents the great contribution of offering an operational definition to the category. Such a

\footnotetext{
4 "When we establish or propose one meaning to a word or expression, wishing that such meaning will be accepted to the effects of the ideas we support, we are fixing an Operational Definition [...]"(everything bold in the original) (Ibid., p. 37. Free translation.). Original text in Portuguese: "Quando nós estabelecemos ou propomos uma definição para uma palavra ou expressão, com o desejo de que tal definição seja aceita para os efeitos das idéias que expomos, estamos fixando um Conceito Operacional [...]".

5 Official data by UNHCR, accessed May 02, 2012, http://www.acnur.org/t3/portugues /recursos/estatisticas/.

${ }^{6}$ Earl E. Huyck and Leon F. Bouvier apud Paulo Borba Casella, "Refugiados," Revista de Informação Legislativa 21, no. 84 (1984): 251-60, accessed April 27, 2012, http://www2.senado .gov.br/bdsf/item/id/181584.

${ }^{7}$ José Henrique Fischel de Andrade, "Breve Reconstituição Histórica Da Tradição Que Culminou Na Proteção Internacional Dos Refugiados," in O Direito Internacional Dos Refugiados: Uma Perspectiva Brasileira, ed. Nadia de Araujo and Guilherme Assis de Almeida (Rio de Janeiro: Renovar, 2001), 120 121.

${ }^{8}$ Ibid., 99. Free translation. Original text in Portuguese: “[...] materializada no estabelecimento de organizações que têm como escopo a assistência e a proteção dos refugiados [...]".

${ }^{9}$ Ibid., 99-100. Free translation. Original text in Portuguese: “[...] que ocorre por meio da redação de instrumentos convencionais, extraconvencionais e domésticos, os quais conceituam o termo 'refugiado' e definem o estatuto jurídico de seus beneficiários".
} 
definition is decisive in marking the contractual or conventional obligations of the signatory States of that instrument, once it contains the essential elements that characterize a refugee ${ }^{10}$. Ipsis litteris, the Convention asserts:

"For the purposes of the present Convention, the term 'refugee' shall apply to any person who: [...] As a result of events occurring before 1 January 1951 and owing to well-founded fear of being persecuted for reasons of race, religion, nationality, membership of a particular social group or political opinion, is outside the country of his nationality and is unable or, owing to such fear, is unwilling to avail himself of the protection of that country; or who, not having a nationality and being outside the country of his former habitual residence as a result of such events, is unable or, owing to such fear, is unwilling to return to it." "11

When it was signed in 1951, the Convention established two restrictions: a temporal one, which made the characterization of Refugees depend on events prior to $1^{\text {st }}$ January 1951, and a geographic one, which limited the characterization of Refugees to events that had taken place in the European continent ${ }^{12}$. Nevertheless, both these restrictions were lifted by the 1967 Protocol, which states:

"For the purpose of the present Protocol, the term 'refugee' shall [...] mean any person within the definition of article 1 of the Convention as if the words 'As a result of events occurring before 1 January 1951 and ...' 'and the words'... 'a result of such events', in article $1 \mathrm{~A}(2)$ were omitted.

"The present Protocol shall be applied by the States Parties hereto without any geographic limitation $[\ldots]]^{\prime 13}$

Thus, without the temporal and geographic restrictions, the definition of the 1951 Convention, which is also adopted by this article, imposes three conditions for the characterization of a refugee situation: 1) A well-founded fear of persecution; 2) International Migration; and 3) A lack of protection from the country of origin.

The well-founded fear of persecution is "the crucial criterion in defining a refugee $[\ldots]$ "14. Nonetheless, there is neither a generally accepted definition of persecution nor a uniform interpretation of the term. The recognition of the status of refugees is a task to be performed by each State ${ }^{15}$, at the moment they decide about the concession of territorial asylum ${ }^{16}$. Besides that, the definition does not demand actual persecution, but a well-founded fear of persecution, which implies

\footnotetext{
${ }^{10}$ Casella, "Refugiados," 253.

11 United Nations, Convention Relating to the Status of Refugees (Geneva, 1951), accessed April 12, 2012, http://www.unhcr.org/3b66c2aa10.html, art. 1-A(2). No bold in the original text.

12 United Nations, Convention Relating to the Status of Refugees, art. 1-B(1).

13 United Nations, Protocol Relating to the Status of Refugees, 1967, http://www.unhcr.org/3b66 c2aa10.html. art. 1(2) e (3).

14 Paulo Borba Casella, "Refugiados: Conceito E Extensão," in O Direito Internacional Dos Refugiados: Uma Perspectiva Brasileira, ed. Nadia Araujo and Guilherme Assis de Almeida (Renovar, 2001), 20. Free translation. Original text in Portuguese: “[o] critério crucial para conceituar um refugiado [...]”.

15 Antonio August Cançado Trindade, "A Proteção Dos Refugiados Em Seus Aspectos Jurídicos: A Convenção de Genebra de 1951 Relativa Ao Estatuto Do Refugiado E a Questão Do Levantamento Pelo Brasil Da Reserva Geográfica," in Pareceres Dos Consultores Jurídicos Do Itamaraty, Volume 8, ed. Antonio Paulo Cachapuz Medeiros (Brasília: Conselho Editorial do Senado Federal, 2004), 302.

16 When a State receives a Refugee in its territory, it grants him/her territorial asylum. The territorial asylum should not be confused with the political or diplomatic asylum, "[...] which is granted to persecuted persons for political reasons and is granted in "legations, warships, military airplanes and military camps'." (Celso Duvivier de Albuquerque Mello, Direito Constitucional Internacional, 2nd ed. (Rio de Janeiro: Renovar, 2000), 161. Free translation. Original text in Portuguese: “[...] que é concedido a perseguidos por motivos políticos e que é concedido nas 'legações, navios de guerra, aeronaves militares e acampamentos militares'.”).
} 
the presence of a subjective element inherent in the asylum seeker ${ }^{17}$. Nevertheless, the operational definition of the term " persecution" is essential for this article. It is a sine qua non condition for the recognition of the refugee status under the rules of the 1951 Convention and, therefore, it will be used in the analysis of the applicability (or inapplicability) of the global system of Refugee protection to the case of EDPs ( $v$. item 3).

The UNHCR Handbook on Procedures and Criteria for Determining Refugee Status under the 1951 Convention and the 1967 Protocol relating to the Status of Refugees (hereinafter only the UNHCR Handbook) offers an indication of what persecution might be:

"From Article 33 of the 1951 Convention, it may be inferred that a threat to life or freedom on account of race, religion, nationality, political opinion or membership of a particular social group is always persecution. Other serious violations of human rights - for the same reasons - would also constitute persecution.

"Whether other prejudicial actions or threats would amount to persecution will depend on the circumstances of each case $[\ldots]$ "18

The 1993 UNHCR Report is also helpful for the understanding of the category persecution. Approaching the displacement dynamics and the main causes of Refugee fluxes, the Report remarks that: "The 1951 Convention identified what is still a major root cause of refugee flows: persecution based on who the refugee is (race, nationality, membership of a particular social group) or what he or she believes (religion or political opinion)." ${ }^{\prime 19}$

In view of both the UNHCR Handbook and the 1993 Report, the following operational definition of persecution is proposed, in order to make that category an instrument of analysis for this article, with no intention to build a universally accepted definition though. Thus, persecution is considered as the harmful action, or threat of such an action, perpetrated against a person or a group of persons, based on who that person is - race, nationality or membership of a particular social group - or what he or she believes in - religion or political opinion.

The second condition imposed by the 1951 Convention to the recognition of the refugee status requires that the individual be already outside the country of their nationality, i.e. an international migration must have happened. international migration is understood here as the displacement of an individual (or a group of individuals) that leaves the country of his/her nationality or where he/she possesses habitual residence and settles himself/herself in another country. As a consequence, internal migrants, who leave their residences and move somewhere else inside their own country, are not considered as refugees, even when they are victims of persecution. In light of this, the 1993 UNHCR Report stated: "The situations that produce refugees also produce other forms of displacement, including people who

\footnotetext{
17 United Nations High Commissioner for Refugees, Handbook on Procedures and Criteria for Determining Refugee Status under the 1951 Convention and the 1967 Protocol Relating to the Status of Refugees (Geneva: UNHCR, 1992), accessed May 04, 2012, http://www.unhcr.org/3d58e13b4.html, paragraphs 37-50.

${ }_{18}$ United Nations High Commissioner for Refugees, Handbook on Procedures and Criteria for Determining Refugee Status under the 1951 Convention and the 1967 Protocol Relating to the Status of Refugees, paragraphs 51-52.

${ }^{19}$ United Nations High Commissioner for Refugees, The State of the World's Refugees 1993: The Challenge of Protection (Genova: UNHCR, 1993), accessed May 18, 2012, http://www.unhcr.org/3eeedcf7 a.html, specifically chap. 1: The Dynamics of Displacement.
} 
have not crossed an international border but face the same fears and dangers as refugees. ${ }^{20}$

The third condition set by the 1951 Convention determines that the refugee's country of origin (or where he or she has his/her habitual residence) does not grant $\mathrm{him} /$ her due protection against persecution or the refugee is unwilling, owning to the fear of persecution, to avail himself/herself of the protection of his/her country. That means that the State where the refugee is from is always involved with the persecution situation that generated the migratory flux, either because 1) the State where the refugee is from is the agent of the persecution; or 2) the State where the Refugee is from is not the agent of the persecution, but it does not take the necessary measures to make the persecution cease. In both cases, the person is unable to avail himself/herself of the protection of his/her own country and ends up seeking asylum beyond borders. This "abandonment" is what originates the situations provided by the other two conditions: as one cannot trust one's own State, one is faced with a well-founded fear of persecution and one leaves one's home, migrating internationally, in order to defend one's life, freedom and security seeking refuge in another country. For that reason, Flávia Piovesan asserts: "each refugee is a consequence of a State that violates human rights"21.

With the combination of these three conditions (fear of persecution, international migration and lack of protection from the country of origin), the refugee status is determined and must be recognized by the States of the international community ${ }^{22}$, especially the signatories of the 1951 Convention and its 1967 Protocol. That is the precise orientation of the UNHCR Handbook:

"A person is a refugee within the meaning of the 1951 Convention as soon as he fulfills the criteria contained in the definition. This would necessarily occur prior to the time at which his refugee status is formally determined. Recognition of his refugee status does not therefore make him a refugee but declares him to be one. He does not become a refugee because of recognition, but is recognized because he is a refugee." 23

The 1951 Convention and the 1967 Protocol are not the only instruments that contain an operational definition for the term "refugee". At least two other documents address that matter and set even larger definitions of the term, than the ones set by the 1951 Convention. Such documents are the Organization of African

${ }^{20}$ United Nations High Commissioner for Refugees, The State of the World's Refugees 1993: The Challenge of Protection.

${ }^{21}$ Flávia Piovesan, "O Direito de Asilo E a Proteção Internacional Dos Refugiados," in O Direito Internacional Dos Refugiados: Uma Perspectiva Brasileira, ed. Nadia de Araujo and Guilherme Assis de Almeida (Rio de Janeiro: Renovar, 2001), 38. Free translation. Original text in Portuguese: "cada refugiado é conseqüência de um Estado que viola os Direitos Humanos".

${ }^{22}$ Granting a Refugee territorial asylum is an act of sovereignty and, thus, it is not mandatory to the State. As Geraldo Eulálio do Nascimento e Silva reminds, "[...] granting asylum is a right of the State based on its sovereignty". And he adds: "[...] there is no right to asylum, i.e. the State, in the exercise of the right of sovereignty, has the right to refuse it". (Geraldo Eulálio do Nascimento e Silva, "Os Refugiados Políticos e o Asilo Territorial," in O Direito Internacional dos Refugiados: Uma Perspectiva Brasileira, ed. Nadia de Araujo and Guilherme Assis de Almeida (Rio de Janeiro: Renovar, 2001), 1314. Translations by the authors of the article. Original texts in Portuguese, respectively: "[...] a concessão do asilo é um direito do Estado baseado em sua soberania" and "[...] não existe um direito ao asilo, ou seja o Estado, no exercício de seu direito de soberania, tem o direito de recusá-lo”.).

On the other hand, Flávia Piovesan sustains that the non refoulement principle, by which it is prohibited to return the Refugee to the country where his/her life and freedom are threatened, must be recognized and respected by all the international community, for it is a principle of jus cogens. (Piovesan, "O Direito de Asilo E a Proteção Internacional Dos Refugiados," 47-48.).

${ }^{23}$ United Nations High Commissioner for Refugees, Handbook on Procedures and Criteria for Determining Refugee Status under the 1951 Convention and the 1967 Protocol Relating to the Status of Refugees, paragraph 28. 
Unity (OAU) Convention Governing the Specific Aspects of Refugee Problems in Africa (1969) and the Cartagena Declaration (1984). According to Flávia Piovesan, both instruments, besides adopting the definition from the 1951 Convention, "[...] prescribe the massive violation of human rights as a characteristic refugee situation" 24 . However, both the OAU Convention and the Cartagena Declaration are regional instruments, applicable only to Africa and Latin America, respectively. For that reason, the enlargements in the definition of Refugee contained in those instruments are not adopted by this article, which proposes, as was earlier stated, to analyze the global system of refugee protection in order to verify the possibility of its application to cases implicating EDPs. Therefore, this article sticks to the definition of the 1951 Convention and the conditions therein imposed for Refugee characterization.

\section{Environmentally Displaced Persons}

In 1985, Essam El-Hinnawi, a researcher for the United Nations Environment Programme (UNEP), used the term Environmental Refugee for the first time, defining it as:

"[...] those people who have been forced to leave their traditional habitat, temporarily or permanently, because of a marked environmental disruption (natural and/or triggered by people) that jeopardized their existence and/or seriously affected the quality of their life [sic]. By "environmental disruption" in this definition is meant any physical, chemical, and/or biological changes in the ecosystem (or resource base) that render it, temporarily or permanently, unsuitable to support human life." 25

Even though it has been widely used in the last 25 years, the term "environmental refugee" does not seem appropriate to characterize the situation described by El-Hinnawi ${ }^{26}$. The reason for that assertion takes into account what

${ }^{24}$ Piovesan, “O Direito de Asilo E a Proteção Internacional Dos Refugiados,” 36. Free translation. Original text in Portuguese: “[...] prevêem a violação maciça dos direitos humanos como caracterizadora da situação de refugiado".

The OAU Convention Governing the Specific Aspects of Refugee Problems in Africa, after adopting the same definition of Refugee of the 1951 Convention, extends such definition to include also " $[. .$.$] every person who, owing to external aggression, occupation, foreign domination or events$ seriously disturbing public order in either part or the whole of his country of origin or nationality, is compelled to leave his place of habitual residence in order to seek refuge in another place outside his country of origin or nationality". (Organization of African Unity, Convention Governing the Specific Aspects of Refugee Problems in Africa (Adis-Abeba, 1969), accessed May 04, 2012, http://www.au.int/en/sites/default/files/Convention_En_Refugee_Problems _in_Africa_ AddisAbaba_10September1969_0.pdf, art. 1(2).).

In addition, the Cartagena Declaration recommends that the definition of Refugee, for use in Latin America, should include, besides the cases covered by the 1951 Convention, those cases of "[...] persons who have fled their country because their lives, safety or freedom have been threatened by generalized violence, foreign aggression, internal conflicts, massive violation of human rights or other circumstances which have seriously disturbed public order". (Coloquio Sobre la Protección Internacional de los Refugiados en Améca Central México y Panamá, Cartagena Declaration on Refugess (Cartagena, 1984), accessed May 04, 2012, http://www.asylumlaw.org/docs/international /CentralAmerica.PDF, Third Conclusion.).

25 Essam El-Hinnawi apud Diane C. Bates, "Environmental Refugees? Classifying Human Migrations Caused by Environmental Change," Population and Environment 23, no. 5 (2002): 466. No bolds in the original text.

26 “The expression 'environmental refugees', though widely used for the past twenty years, is mistakenly applied." (Aurelie Lopez, "The Protection of Environmentally-Displaced Persons in International Law," Environmental Law 36, no. 2 (2007): 365-409, accessed April 11, 2012, 
has been explained in the previous part of this article. When one talks about refugees, one is referring to a series of criteria (fear of persecution, international migration, as well as lack of protection from the country of origin) that is not evident in the definition proposed above. Ergo, Liliana Jubilut and Silvia Apolinário assert that "from the point of view of international law, the expression environmental refugees is not correct, because the definition given to the word refugee by international law includes specific criteria which permit a person to be granted refuge protection"27.

On account of that, in this article, Essam El-Hinnawi's operational definition is not used to define the term environmental refugee, but to define the term environmentally displaced persons (EDPs), which is more appropriate in the earlier described scenario. The term "displaced" reflects: the plurality of causes of environmental displacements; the not only personal, but also collective characteristic of population movements; as well as the idea that it is not a voluntary migration or a migration motivated by economic needs, but a migration imposed by an ineluctable environmental threat ${ }^{28}$. Julien Bétaille maintains:

"We have chosen the term environmentally displaced persons for two main reasons. First, the term "refugee" recalls the 1951 Geneva Convention, whose text is not adapted to the reality of the phenomenon studied here. Second, the adverb "environmentally" simultaneously allows the inclusion of the displacements connected not only to climate changes, but also to other natural or technological catastrophes. In addition, those terms translate, in a better way, the idea of an imposed migration, rather than a voluntary one." ${ }^{29}$

Thus, the term EDPs is used here to describe the person or group of persons that is forced to leave the place he/she lives due to an environmental disruption. This phenomenon is one of the most significant challenges of the contemporary international community. For an idea of the scale of environmental displacements, one should remember Norman Myers' estimates. According to Myers, in 1997 there were at least 25 million EDPs in the world, located mainly in Sub-Saharan Africa, the Indian sub-continent, China, Mexico and Central America. That is equivalent to saying that, in 1997, for every 225 persons, at least one of them could be characterized as an EDP. Still in accordance with Myers, the environmental displacement matter promises to rank as one of the foremost human crises of our

http:/ / elawreview.org/2007/10/the-protection-of-environmentally-displaced-persons-in-internation al-law/, I. Introduction.).

27 Liliana Lyra Jubilut and Silvia Menicucci O. S. Apolinário, "A Necessidade de Proteção Internacional No Âmbito Da Migração," Revista Direito GV 6, no. 1 (2010): 288, accessed April 11, 2012, http://www.scielo.br/pdf/rdgv/v6n1/13.pdf. Italics in the original text.

28 Jean-Marc Lavieille, Julien Bétaille, and Jean-Pierre Marguénaud, "Rapport Explicatif Du Projet de Convention Relative Au Statut International Des Déplacés Environnementaux," Revue de Droit de l'Université de Sherbrooke, 2008, 462, accessed May 11, 2012, http://www.usherbrooke.ca/droit / fileadmin/sites/droit/documents/RDUS/volume_39/39-12-convention.pdf.

${ }^{29}$ Julien Bétaille, "Les Déplacements Environnementaux: Un Defi Pour le Droit International," L'encyclopédie Du Développement Durable, accessed April 12, 2012, http://encyclopediedd.org/encyclopedie/territoires/3-0-demographie/les-deplacements-environnementaux.html, Introduction. Free translation. Original text in French: "Nous choisissons ici le terme de déplacés environnementaux, ce pour deux raisons principales. La première est que le terme 'réfugié' renvoie à la Convention de Genève de 1951 et que ce texte n'est pas adapté à la réalité du phénomène ici étudié. La seconde est que l'adjectif 'environnementaux' permet d'englober à la fois les déplacements liés au changement climatique mais aussi à d'autres catastrophes naturelles ou technologiques. De plus, ces termes traduisent mieux l'idée selon laquelle la migration est subie et non choisie." 
times $^{30}$. Jodi Jacobson attests that EDPs "[...] have become the single largest class of displaced persons in the world [...]"31.

It is possible to have a glimpse of the complexity of those migrations motivated by environmental changes through Diane C. Bates's classification of EDPs ${ }^{32}$. As reported by Bates, those migration fluxes are born of three different kinds of environmental changes: disasters, expropriations and deteriorations.

The first of these kinds of environmental changes (the disasters) are "acute disruptions in the environment that cause unplanned human migration [...]"33. The environmental disasters can be divided in natural events (volcanic eruptions, hurricanes, earthquakes) and technological accidents (Chernobyl, in 1986; Fukushima, in 2011).

The expropriations (the second kind of environmental changes that cause migration fluxes) include "[...] the permanent displacement of people whose habitat is appropriated for land use incompatible with their continued residence" ${ }^{\text {"34 }}$. The expropriations are consequences of development (flooded areas for building a dam, urban expansion in natives' territory) or war (ecocide, understood as "[...] the intentional destruction of human environments in order to strategically relocate a target population during a period of war" ${ }^{35}$ ).

Finally, the deteriorations (third kind of environmental changes mentioned by Bates) are gradual environmental changes of human origin, caused by pollution ("[...] the release of toxic substances into the environment that gradually impairs human health or the ability of residents to sustain their quality of life" ${ }^{\prime 36}$ - e.g. global warming) or depletion ("[...] the gradual removal of some part of the ecosystem" ${ }^{\prime 37}$ - e.g. deforestation).

\footnotetext{
30 Norman Myers, "Environmental Refugees," Population and Environment 19, no. 2 (1997): 167-82, accessed April 16, 2012, http://www.springerlink.com/content/j436x24814660277/ fulltext.pdf, 167, 168, 175.

31 Jodi Jacobson apud Steve Lonergan, "The Role of Environmental Degradation in Population Displacement," Environmental Change and Security Project Report, no. 4 (1998): 5-15, April 17, 2012, http://www.wilsoncenter.org/sites/default/files/ACF1493.pdf, 8.

32 Bates, "Environmental Refugees? Classifying Human Migrations Caused by Environmental Change," 469-475.

33 Bates, "Environmental Refugees? Classifying Human Migrations Caused by Environmental Change," 469.

34 Bates, "Environmental Refugees? Classifying Human Migrations Caused by Environmental Change," 471-472.

35 Bates, "Environmental Refugees? Classifying Human Migrations Caused by Environmental Change," 472.

36 Bates, "Environmental Refugees? Classifying Human Migrations Caused by Environmental Change," 474.

37 Bates, "Environmental Refugees? Classifying Human Migrations Caused by Environmental Change," 474.
} 
Summing up in a table ${ }^{38}$ :

\begin{tabular}{|c|c|c|c|c|c|c|}
\hline \multirow[b]{2}{*}{$\begin{array}{l}\text { Sub- } \\
\text { Category }\end{array}$} & \multicolumn{2}{|c|}{$\begin{array}{c}\text { Disaster } \\
\text { An unintended, catastrophic } \\
\text { event triggers human migration }\end{array}$} & \multicolumn{2}{|c|}{$\begin{array}{c}\text { Expropriation } \\
\text { The willful } \\
\text { destruction of } \\
\text { environment renders it } \\
\text { unfit for human } \\
\text { habitation } \\
\end{array}$} & \multicolumn{2}{|c|}{$\begin{array}{c}\text { Deterioration } \\
\text { An incremental } \\
\text { deterioration of the } \\
\text { environment compels } \\
\text { migration as constraints to } \\
\text { human survival increase }\end{array}$} \\
\hline & Natural & Technological & $\begin{array}{l}\text { Developme } \\
\text { nt }\end{array}$ & Ecocide & Pollution & Depletion \\
\hline Origin & Natural & Anthropogenic & $\begin{array}{l}\text { Anthropoge } \\
\text { nic }\end{array}$ & Anthropogenic & Anthropogenic & Anthropogenic \\
\hline $\begin{array}{l}\text { Intention } \\
\text { of } \\
\text { Migratio } \\
\mathrm{n}\end{array}$ & $\begin{array}{l}\text { Unintentiona } \\
1\end{array}$ & Unintentional & Intentional & Intentional & Unintentional & Unintentional \\
\hline Duration & Acute & Acute & Acute & Acute & Acute & Gradual \\
\hline
\end{tabular}

Diane Bates' classification allows perceiving the great complexity of the category EDPs. Among natural and anthropogenic causes as well as intentional and unintentional ones, permanent and temporary displacements as well as acute and gradual ones, the category EDPs includes a wide range of situations with their own characteristics, their own causes and their own consequences.

As a result, the multiple aspects of this complex phenomenon cannot be ignored in pursuing the objective initially proposed in this article. The verification of applicability of the global system of refugee protection to EDPs must necessarily consider the plurality of that phenomenon. Such is the analysis made in the next item.

\section{The global system of Refugee protection and the Environmentally Displaced Persons}

To verify the applicability of the 1951 Convention to Environmentally Displaced Persons one must analyze the compatibility between the EDPs' situation and the criteria for refugee recognition as presented in the first part of this article. However, as it has been concluded above, the studied phenomenon is complex, for it includes an extensive range of situations. In order to systematize those different situations in a useful way to achieve the objective initially established by this article, it is proposed to consider the category "EDPs" (environmentally displaced persons) a genus under which is possible to find at least two species: environmentally persecuted persons and environmentally displaced persons Stricto Sensu.

The difference between environmentally persecuted persons and environmentally displaced persons Stricto Sensu is in the presence or absence of the fear of environmental persecution. An environmental persecution happens when environmental disruptions are used as means or strategy of persecution against an individual or a group of individuals. About that, the 1993 UNHCR Report states: "Occasionally, the destruction of a habitat takes on the character of persecution -

38 The table was adapted by the authors of the article. Original table in: Bates, "Environmental Refugees? Classifying Human Migrations Caused by Environmental Change,” 470. 
for example if it occurs as a result of deliberate governmental action or gross negligence and no effort is made to compensate or assist the people affected." ${ }^{\prime 39}$

Therefore, on account of the operational definition proposed to the term "persecution", it is possible to define environmental persecution as the use of environmental disruptions to harm a person or a group of persons based on who the person is - race, nationality or membership of a particular social group - or what he or she believes in - religion or political opinion. The environmental persecution can be active or passive. In active environmental persecution, the environmental disruption is caused directly by the agent of the persecution, aiming to harm and/or cause the displacement of victims. Passive environmental persecution happens when, in face of a natural disaster or an environmental accident (unintentional disruptions), the competent authorities to assist the victims (usually the State) do not assist them for reasons relating to who those persons are or what they believe in.

In both cases, the reasons for actively causing environmental disruptions or neglecting assistance to persons affected by unintentional disruptions are the key elements necessary for the situation to be classified as persecution. As a consequence, the mere (financial, organizational, structural...) incapacity of a certain State to properly address the situation of persons affected by environmental disruptions is not sufficient to constitute environmental persecution. The agent of persecution must be willing to harm and/or cause the displacement of the victims because of who they are or what they believe in.

In addition, environmental persecution might just be one strategy within a bigger campaign of persecution, which may involve a myriad of fundamental right violations. Acts of persecution prior to the environmental disruption may be quite helpful when evaluating the behavior of a State, especially when it neglects assistance to persons affected by unintentional disruptions. Prior persecution illustrate the reasons behind State negligence and might be the deciding factor in establishing the difference between passive environmental persecution and the incapacity of the State in properly addressing cases concerning persons affected by environmental disruptions.

In this context, and bearing in mind the Essam El-Hinnawi's definition adopted here to the genus EDPs, the category "environmentally persecuted person" is defined as that person who is forced to leave their traditional habitat, temporarily or permanently, because of well-founded fears of environmental persecution that compromises their existence and/or seriously affects their quality of life.

And if the environmental persecution is the differentiating factor between the environmentally persecuted person and the environmentally displaced person stricto sensu, then this last one can be defined as the person that is forced to leave his/her traditional babitat, migrating internally or internationally, temporarily or permanently, due to a specific environmental disruption (natural and/or anthropogenic) that compromises his/her existence and/or seriously affects his/her quality of life, without constituting environmental persecution.

Nonetheless, it is not enough to classify EDPs as environmentally persecuted persons and environmentally displaced persons stricto sensu. In the environmentally persecuted person category, one must distinguish those persons who migrate internally from those who migrate internationally. Persons who migrate internationally, motivated by well-founded fears of environmental persecution, not

${ }^{39}$ United Nations High Commissioner for Refugees, The State of the World's Refugees 1993: The Challenge of Protection. 
benefiting from their country protection and not being able to go back to it, are called environmental refugees.

It is important to highlight that the category "environmental refugee" is used here with a completely different meaning from that which was given to it by Essam El-Hinnawi. Environmental refugees make a very special class of EDPs. They combine every criterion to be recognized, at the same time, as refugees under the rule of the 1951 Convention and as environmentally persecuted persons - a species of the genus EDPs, according to the remarks above. By way of visual illustration, the overlapping area of two intersecting circles can be said to represent environmental refugees:

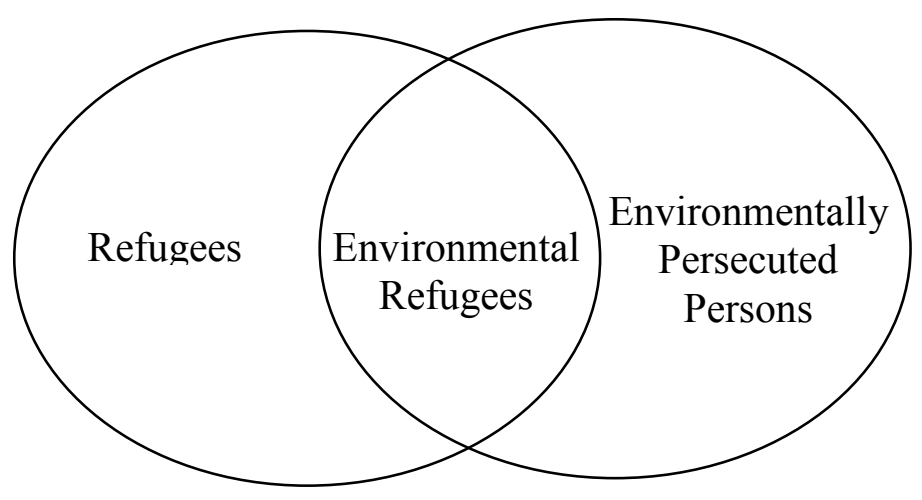

Consequently, the most appropriate definition of the "environmental refugee" category is a fusion between the definitions of refugee and environmentally persecuted person. As a result, an environmental refugee is understood in this article as any person who is forced to leave their country of nationality, temporarily or permanently, due to a well-founded fear of environmental persecution that compromises their existence and/or seriously affects their quality of life, and is unable or unwilling, due to such fear, to avail himself/herself of the protection of that country; or who, not having a nationality and being outside the country of his/her former habitual residence, due to a well-founded fear, is unable or unwilling to return to it.

Classifying EDPs in environmentally displaced persons stricto sensu, environmentally persecuted persons and environmental refugees allows a much clearer perception of the subject relating to the applicability of the global refugee protection system. The 1951 Convention and the 1967 Protocol can be applied to EDPs, but not in every situation. The authority of the Convention and its Protocol is conditioned to the verification of all three criteria to the recognition of a refugee situation: well-founded fear of persecution, international migration and lack of protection from the refugee's country of origin. Consequently, the convention and the protocol apply only to that type of EDPs that fulfill those three criteria, i.e., to the environmental refugees. They apply neither to other environmentally persecuted persons nor to environmentally displaced persons stricto sensu.

Thus far, the global system of refugee protection can be used to guarantee the fundamental rights of a very specific group of EDPs (the environmental refugees), however, it is not enough to deal with the growing number of persons who migrate internally and internationally, motivated by environmental disruptions, but not consumed by the fear of environmental persecution. Once they abandon their homes, these human beings are submitted to the most degrading conditions, witnessing the violation of their fundamental rights, including their rights to life, 
general freedom, freedom from torture, privacy, family life, as well as freedom from arbitrary exile etc. ${ }^{40}$

All these rights are embodied in an extensive list of international treaties such as: The Universal Declaration of Human Rights (1948); The International Covenant on Civil and Political Rights (1966); The International Covenant on Economic, Social and Cultural Rights (1966); The Convention on the Prevention and Punishment of the Crime of Genocide (1948); The Convention against Torture and Other Cruel, Inhuman or Degrading Treatment or Punishment (1984); The Convention on the Elimination of All Forms of Racial Discrimination (1965); The Convention on the Rights of the Child (1989); as well as other instruments that make up international human rights law.

That is why Érika Pires Ramos warns that the normative void relating to the situation of EDPs "[...] is not consistent with the current stage of developments in International Law, especially with the international protection of the human person - understood broadly —, in which the environmental dimension is inserted $[\ldots]^{344}$.

Along these lines, the protection of the fundamental rights of EDPs depends inexorably on the international recognition of their own legal statute. In regards to this, Michel Prieur's contribution is invaluable. Alongside a group of eight experts in the theme $\mathrm{e}^{42}$ and with the patronage of CRIDEAU, he has written the Convention Project Relating to the International Statute of Environmentally Displaced Persons $^{43}$. The document has a definition and a classification of EDPs and embodies the principles and rights that must be guaranteed to them. It also provides for the creation of a specialized Agency to deal with migration fluxes of EDPs.

However commendable it may be, this enterprise is still an academic initiative and hasn't been submitted to political negotiation yet. Current efforts must be directed mainly to drawing the attention of the global community to the pressing problem of EDPs. Admitting the existence of such a group of people and recognizing the lack of protection of their fundamental rights is of utmost importance. As Jean Lambert declares: "By recognizing environmental refugees you recognize the problem. By recognizing the problem you start on the road to accepting responsibility and implementing solutions." ${ }^{\prime 4}$ And what a long road it still is.

\section{Final considerations}

The problem of EDPs is already one of the most relevant challenges of contemporary international community. This global and extremely complex phenomenon is yet to be properly handled by the legal community in the

\footnotetext{
40 Piovesan, “O Direito de Asilo E a Proteção Internacional Dos Refugiados,” 30. The author's comment is about Refugees, but is perfectly adequate to the Environmentally Displaced Persons' situation.

41 Érika Pires Ramos, "Refugiados Ambientais: Em Busca de Reconhecimento Pelo Direito Internacional" (PhD thesis, Universidade de São Paulo, 2011). 112. Free translation. Original text in Portuguese: “[...] não se coaduna com o atual estágio de evolução do próprio Direito Internacional, especialmente com a proteção internacional da pessoa humana — entendida de forma ampla —, na qual se insere a dimensão ambiental [...]".

42 Jean-Pierre Marguenaud, Gérard Monediaire, Julien Betaille, Bernard Drobenko, Jean-Jacques Gouguet, Jean-Marc Lavieille, Séverine Nadaud e Damien Roets.

43 Prieur et al., "Projet de Convention Relative Au Statut International Des Déplacés Environnementaux."

44 Jean Lambert apud Ramos, "Refugiados Ambientais: Em Busca de Reconhecimento Pelo Direito Internacional," 5.
} 
international sphere. As a result, millions of persons witness the violation of their fundamental rights with no access to any international institution capable of guaranteeing the enforcement of the rules embodied in the 1948 Universal Declaration of Human Rights and in the body of international human right laws, developed from such Declaration.

The complexity of the theme demands a particular treatment for the terms "refugee" and "environmentally displaced person", especially because international law does not provide for any legal differentiation between them, even though they are related to completely different situations.

The issue has had international repercussion, notably in regions particularly vulnerable to environmental disasters that cause population displacements. In these areas, individuals or groups of individuals abandon temporarily or permanently their homes pressed by environmental problems.

A new category arises: the environmentally displaced persons - EDPs. With no explicit mention in the 1951 Convention, this new category has been the subject of a lot of international discussion.

In order to fulfill a normative gap, this article tried to verify the possibility of applying the global refugee protection system to cases relating to EDPs. To do so, the criteria imposed by the 1951 Convention and its 1967 Protocol for determining a refugee situation was analyzed. From the definition of the category "refugee", it was possible to identify three different conditions to the recognition of the refugee quality: a well-founded fear of persecution, international migration and a lack of protection from the refugee's country of origin.

Subsequently, the EDP phenomenon was portrayed in its complexity, demonstrating the variety of situations that fit in the category.

In view of that variety, EDPs were classified in two species: environmentally persecuted persons and environmentally displaced persons stricto sensu. Among environmentally persecuted persons, a specific group of persons was distinguished: those who were able to cross their country borders, migrating internationally. Those persons were referred to as environmental refugees.

This classification has allowed a compatibility judgment between the various types of EDPs and the characterization criteria for the "refugee" category, imposed by the global system of refugee protection. As a result, it was concluded that the Refugee Convention and Protocol could only be applied to that very specific class of environmental refugees, because it is the only type of EDPs in which it is possible to verify the well-founded fear of persecution (in the form of environmental persecution), the international migration and the lack of protection from the country of origin. The other environmentally persecuted persons and the environmentally displaced persons stricto sensu still have no legal status and no globally enforceable international instrument capable of materializing the assurances of international human rights law to these vulnerable groups.

Therefore, there is an urgent need to create a globally enforceable international instrument providing EDPs with a legal status, recognizing and guaranteeing their fundamental rights, as well as creating a specific protection institution or agency to enforce those rights. In that sense, the academic initiative of Michel Prieur and his team from CRIDEAU to compose the Convention Project Relating to the International Statute of Environmentally Displaced Persons is praiseworthy. But there is still a long road ahead in the implementation of the solutions suggested by that team of experts. The issue of EDPs still has to reach the political agenda of negotiations and in so doing, drawing the attention of the international community to the problem at hand is just the first step. 